\title{
Religious conversion, transformative experience, and disagreement ${ }^{1}$
}

\author{
Helen De Cruz, Oxford Brookes University, hde-cruz@brookes.ac.uk
}

This is a draft version of a paper that appeared in Philosophia Christi, vol 20 (1), 265-276

\section{Religious conversion and the Independence Principle}

Miguel and Catherine are both atheist philosophers and long-time friends from graduate school. Miguel respects Catherine and believes she is his epistemic peer. Both of them have been raised in a liberal environment where atheism is quite widespread. But they have also carefully thought about theism. Neither of them is a philosopher of religion, but they know the arguments for and against theism and they both agree that the arguments against outweigh the arguments for. As a result, both are quite complacent atheists; ${ }^{2}$ they think there is no serious case to be made for theism.

Miguel meets Catherine at a philosophy conference-it's been about a year since they last met. He has been looking forward to seeing his old friend. As they catch up over a cup of coffee, it becomes clear that Catherine is now a theist.

"But why?" Miguel asks. "Didn't you think all that theist philosophy is dubious, motivated reasoning?"

"I changed my mind," Catherine replies.

This situation appears to be a case of peer disagreement. Miguel and Catherine are (presumably) equally thoughtful in the domain in question, and they have access to the same evidence. While their epistemic situation is not identical, they will still be similar enough to take each other to be epistemic peers, a situation that occurs frequently in everyday life.

Epistemologists have debated whether one should conciliate, that is, revise one's opinion that $p,{ }^{3}$ when faced with a disagreeing peer who holds that not- $p$, or whether one can remain steadfast. One principle that has been proposed to separate these two types of responses is the Independence Principle.

Independence: In evaluating the epistemic credentials of another's expressed belief about $p$, in order to determine how (or whether) to modify

\footnotetext{
${ }^{1}$ This research was supported by research leave funded by Oxford Brookes University. The author wishes to thank Liam Kofi Bright, Kate Kirkpatrick, Stephen Boulter, Johan De Smedt, Chad Bogosian, and Paul Copan for helpful comments to an earlier draft.

2 The phrase "complacent atheist" was coined by Feldman, and is also used by Littlejohn. See Richard Feldman, "Reasonable Religious Disagreement," in Philosophers without Gods: Meditations on Atheism and the Secular Life, ed. Louise Antony (Oxford: Oxford University Press, 2007), 194-214; Clayton Littlejohn, "Disagreement and Defeat," in Disagreement and Scepticism, ed. D.E. Machuca (London and New York: Routledge, 2013), 169-192.

${ }^{3}$ Some conciliationists think that disagreeing parties should lower their credence that $\mathrm{p}$ to split the difference with their peer (See, e.g., Adam Elga, "Reflection and Disagreement," Noûs 41 (2007): 478-502). Here I will not assume that one needs to split the difference in order to be a conciliationist.
} 
my own belief about $p$, I should do so in a way that doesn't rely on the reasoning behind my initial belief about $\mathrm{p.}^{4}$

Independence delivers a plausible verdict in a variety of cases, such as Christensen's paradigmatic mental math case, where people disagree about the amount to pay in a restaurant where they are splitting the bill. ${ }^{5}$ But the principle might not apply to other cases. An example is elementary math, ${ }^{6}$ where someone you consider as an epistemic peer says that $2+2=5$. This is no reason to lower your confidence that $2+2=4$, but rather, to revise your belief that this person is an epistemic peer, at the very least about elementary mathematical facts. If someone truly believed that $2+2=5$, this would demonstrate that this person is, in all likelihood, not as clear-headed as you.

Would a religious conversion be more analogous to the mental math or the elementary math case? Many people have a response along these lines: "I don't know what happened to Josh. He was such a reasonable guy, but then he joined Scientology. I think he's gone off the cliff," or, "I used to respect Amy, but now she is no longer an Evangelical Christian; I cannot respect her anymore." In such cases, people treat the conversion as a situation where one's epistemic peer has acquired such an outlandish set of beliefs that they begin to doubt the peerhood, akin to the elementary math case. In other cases, where the new belief is at least a live option (in the Jamesian sense), the case may appear more like the mental math case (e.g., "I'm not Jewish, but it does look like an interesting religion with a rich theology. Yehuda might be right, or I might be"). There is a further problem for treating conversion cases as peer disagreements: religious conversions tend to be transformative. This makes it hard to see whether the person is still one's epistemic peer, or what the proper response should be. As a result of this transformation, the beliefs of a dissenting peer, arising from a religious conversion, do not have straightforward evidential value. ${ }^{7}$

\section{Conversion as a transformative experience}

Some experiences transform us, both in who we are and what we know. L.A. Paul has termed such experiences "transformative experiences." ${ }^{8}$ They are personally transformative, in that they change who you are as a person, and they are epistemically

\footnotetext{
${ }^{4}$ David Christensen, "Disagreement, Question-Begging, and Epistemic Self-Criticism," Philosopher's Imprint 11 (2011): 2.

${ }^{5}$ David Christensen, "Epistemology of Disagreement: The Good News," The Philosophical Review 116, no. 2 (2007): 187-217.

6 Jennifer Lackey, "What Should We Do When We Disagree?" in Oxford Studies in Epistemology vol. 3., ed. Tamar Gendler and John Hawthorne (Oxford: Oxford University Press, 2010), 274-293.

${ }^{7}$ There are several definitions of epistemic peerhood, with some focusing on evidential equality, others focusing on cognitive equality, and yet others on the extent to which agents show epistemic virtues, such as thoughtfulness and thoroughness. Here, I will employ the term "epistemic peer" in a fairly loose notion to mean someone whom we consider as an epistemic peer about a given question, prior to becoming aware of any disagreement or agreement with them, see "What Should We Do When We Disagree" for a related notion.

${ }^{8}$ L.A. Paul, Transformative Experience (Oxford: Oxford University Press, 2014).
} 
transformative, in that they give you new information by virtue of a particular experience that can only be obtained by having that experience. Paul has argued that we cannot rationally make decisions that will transform us because there is an asymmetry between who we are now, and what we know now, and who we will be then. We cannot make a comparison between before and after to calculate the expected utility, for example, adopting a child may be a wonderful experience for my friend, but I may come to regret it. Yet we often make life-changing decisions: moving country, getting married, or joining a religious denomination. Not all transformative experiences are the result of conscious decisions. Becoming long-term ill or disabled is a situation few people choose, yet it transforms what they know (e.g., what it is like to live in the face of imminent death), and who they are (e.g., someone who became blind). The transformative nature of disability is illustrated by how disabled and non-disabled people think about their quality of life: sighted people tend to think being blind is a lot worse than blind people think it is, including blind people who were previously sighted. ${ }^{9}$

Is religious conversion transformative? Saul/Paul's conversion to Christianity on the road to Damascus suggests that a single transformative event can lie at the basis of conversion. As recorded in Acts 9 (in a third-person narrative) and the Pauline epistles such as Galatians 1 (in a first-person narrative), Saul of Tarsus was a Jew who persecuted the early Christian community. On his way to Damascus, where he was extending his mission to have Christians imprisoned, he had a dramatic religious experience: he saw a blinding light, and heard the voice of the risen Christ, who asked him why he was persecuting him. Saul then got baptized, and started missionary work for the nascent Christian Church. This account of conversion in terms of a single dramatic experience shaped subsequent discussions of what conversion is like, for instance in the work of early psychologists such as William James. ${ }^{10}$ Subsequent research into religious conversions suggests a more gradual pattern. Conversions are not single experiences, but rather the cumulative effect of many smaller experiences and decisions. Even among people who self-identify as born-again Christians, the majority experience a gradual, rather than a sudden, conversion to Evangelical Protestantism. ${ }^{11}$ Nevertheless, religious conversions transform a person's system of beliefs (thus are epistemically transformative), and change their personality. This is not so much a change in personality traits, but in goals, feelings, attitudes, and life meaning. ${ }^{12}$

Given that a person, post-conversion, is both epistemically and personally transformed, it becomes difficult to gauge whether a former epistemic peer is still an epistemic peer. For example, Jonathan Edwards has an extensive record of the

\footnotetext{
9 Havi Carel, lan J. Kidd, and Richard Pettigrew, "Illness as Transformative Experience," The Lancet 388 (2016): 1152-1153.

${ }^{10}$ William James, The Varieties of Religious Experience. A Study in Human Nature (London: Penguin, 1902 [1985]).

${ }^{11}$ Richard D. Dixon, Roger C. Lowery, and Lloyd P. Jones, "The Fact and Form of Born-Again Religious Conversions and Sociopolitical Conservatism," Review of Religious Research 34 (1992): 117-131.

${ }^{12}$ Raymond F. Paloutzian, James T. Richardson, and Lewis R. Rambo, "Religious conversion and personality change," Journal of personality 67 (1999): 1047-1079.
} 
deepening of his faith in several phases:

. . . my sense of divine things gradually increased, and became more and more lively, and had more of that inward sweetness. The appearance of everything was altered: there seemed to be, as it were, a calm, sweet cast, or appearance of divine glory, in almost everything. God's excellency, his wisdom, his purity and love, seemed to appear in everything; in the sun, moon, and stars, in the clouds and blue sky, in the grass, flowers, trees, in the water and all nature; which used greatly to fix my mind. ${ }^{13}$

How can we know that Edwards, post-conversion, is in an epistemically better position than before? How can Edwards himself know this is the case?

\section{Disagreement with one's former self}

Conversion thus gives rise to two forms of disagreement-disagreement with one's former self, and disagreement with friends and family. Let's look at someone like Catherine, who is now in disagreement with her former self. She now believes things she would have found implausible just a year ago. Should she accord more credence to her new beliefs? If conversion were solely the result of a careful, rational deliberation, it would seem proper that the convert is more confident about her beliefs postconversion. However, conversion occurs as a result of several factors. These include the desire to be of the same religious denomination of one's family and friends, or the desire for self-improvement and for having a religion that is more in line with one's selfimage. For example, in a qualitative study on French young adults who converted to Islam, several people mentioned that they believed regular prayer and observing food taboos and the Ramadan would help them be more personally disciplined. ${ }^{14}$ Such concerns may be practically rational, but do not say much about the truth or falsity of the beliefs one adopts.

The influential Lofland-Stark mode ${ }^{15}$ of religious conversion outlines two basic conditions that prompt religious conversion: first, persons must feel an acute need or tension within their religious problem-solving perspective, and second, they form affective bonds with members of the new religion/affiliation they convert to, which facilitates the step to the new religious movement. This model has attracted much attention in the social study of religion. More recent sociological accounts of conversion identify two types of attraction of religious movements to new converts: ideological,

\footnotetext{
13 Jonathan Edwards, A Treatise Concerning Religious Affections, in Three Parts (Philadelphia: James Crissy, 1821), xxv.

${ }^{14}$ Mounia Lakhdar, Geneviève Vinsonneau, Michael J. Apter and Etienne Mullet, "Conversion to Islam among French Adolescents and Adults: A Systematic Inventory of Motives," International Journal for the Psychology of Religion 17 (2007): 1-15.

15 John Lofland and Rodney Stark, "Becoming a World-saver: A Theory of Conversion to a Deviant Perspective," American Sociological Review 30 (1965): 862-875.
} 
through offering a new perspective on life, and social, by providing a satisfactory social network. ${ }^{16}$

Thus, conversion seems to be to a large extent the result of irrelevant causal factors, such as the presence of social groups that one might feel at home with and seek closer affiliation with. However, one's original religious beliefs (or lack thereof) are also largely the result of irrelevant influences. Vavova defines an irrelevant influence as follows: ${ }^{17}$

An irrelevant influence for me with respect to my belief that $p$ is one that

(a) has influenced my belief that $p$ and (b) does not bear on the truth of $p$.

There is a continued debate on whether irrelevant influences on our beliefs can act as defeaters. This debate often centers on the question of whether our response to the evidence allows for some latitude, as permissivists propose, or whether a total body of evidence only allows for one rational attitude, as proponents of uniqueness hold. ${ }^{18}$

If we assume that sociologists are right and most conversions are caused by a mixture of social and personal factors, few of which are relevant to the truth of the beliefs, how should a convert evaluate her past self's beliefs? Vavova recommends that in order to evaluate the epistemic significance of irrelevant influences, we need to look at what causes these influences. If the influences give "good independent reason to think that you are mistaken with respect to $p$, you must revise your confidence in $p$ accordingly-insofar as you can." ${ }^{19}$ For instance, if a belief is the result of brainwashing or wishful thinking, this does seem to present substantial higher-order evidence that undermines the belief. Extreme cases of conversion that involve indoctrination or coercive force would thus be cast in a negative light, as indoctrination and coercion are in general poor belief-forming mechanisms. But for many other cases, which involve the typical mixture of social factors and personal motivations, it is not so clear whether these irrelevant influences provide the convert with a good independent reason that she is mistaken with respect to her new beliefs. The factors underlying conversion cases do not seem to be more epistemically vicious or benign than factors underlying original religious belief formation (e.g., parental religious affiliation).

A religious convert has one piece of higher-order evidence that someone who does not convert does not possess, namely first-personal experience of changing one's religious beliefs in a deep and significant way: the convert knows that her religious beliefs can be changed. This is in addition to any first-order evidence that prompted the conversion, e.g., Paul's religious experience on the Road to Damascus. (Note that not all

\footnotetext{
${ }^{16}$ Willem Kox, Wim Meeus, and Harm 't Hart, "Religious Conversion of Adolescents: Testing the Lofland and Stark Model of Religious Conversion," Sociological Analysis 52 (1991): 227-240.

17 Katia Vavova, "Irrelevant Influences," Philosophy and Phenomenological Research (in press, online first), 3.

${ }^{18}$ See for a defense of permissivism, Miriam Schoenfield, "Permission to Believe: Why Permissivism is True and What It Tells Us about Irrelevant Influences on Belief," Noûs 48 (2014): 193-218. For a defense of uniqueness, see Roger White, "Epistemic Permissiveness," Philosophical Perspectives 19 (2005): 445-459.

19 "Irrelevant Influences," 12.
} 
conversion cases involve such first-order evidence; some may be purely the result of social factors and do not offer any first-order evidence, but then the convert still has the second-order evidence of having converted). This might lead a convert to become more accepting and open to the religious views of others (after all, the convert had different religious beliefs prior to her conversion). If Catherine now holds beliefs she found implausible just a year ago, this tells her something meaningful not just about her current religious beliefs, but about the fragility and revisability of religious beliefs in general. Thus it would seem rational for a convert to remain open to the views of dissenting epistemic peers. By contrast, Miguel does not have the relevant experiences that presumably were at least in part the basis of Catherine's conversion. Given that he has not, he should remain open to the possibility that Catherine has relevant evidence that he lacks. Thus, conciliationism seems a rational response in the light of conversion of a former epistemic peer. I will look in more detail at this question in the next section.

\section{Disagreement with a recently converted peer}

I will now look at the question of what (if any) epistemic conclusions Miguel can draw from Catherine's conversion, in the absence of further information (let's assume Catherine had to dash to the airport; so Miguel never gets to hear her reasons). Should it lower his confidence in his complacent atheism? One could argue that Catherine's conversion does not provide Miguel with any new information. Miguel is presumably aware of the distribution of opinions about theism. He knows that most of the world population (about $85-90 \%$ ) are theists (most of these are monotheists), ${ }^{20}$ and that a substantial number of academics (albeit still less than $50 \%$ ) are atheists. ${ }^{21}$ He might also know that $73 \%$ of academic philosophers are atheists. ${ }^{22}$ Since Miguel shares most of his background beliefs with academic philosophers, he would probably consider them to be his epistemic peers. Miguel could maintain his credences accordingly. There does not seem to be any special information gained by an old friend having converted to a belief he does not share.

However, Miguel has acquired one new piece of information: someone with whom he had many background beliefs in common, and whom he has always respected as his epistemic peer, changed her mind on the question of theism. If he considers Catherine to be similar to him in many respects (e.g., shared graduate school experience), they are similar in relevant background knowledge. Thus it would seem epistemically prudent for Miguel to at least follow up with Catherine (e.g., a simple email saying something like, "Hey, Catherine. It was great to meet up with you. I have to

\footnotetext{
${ }^{20}$ Phil Zuckerman, "Atheism. Contemporary Numbers and Patterns." In The Cambridge Companion to Atheism, ed. M. Martin (Cambridge: Cambridge University Press, 2007), 47-65.

${ }^{21}$ Neil Gross and Solon Simmons, "The Religiosity of American College and University Professors," Sociology of Religion 70 (2009): 101-129.

22 David Bourget and David Chalmers, "What do philosophers believe?" Philosophical Studies 170 (2014): 465-500, but see Helen De Cruz, "Religious Disagreement: An Empirical Study among Academic Philosophers," Episteme 14 (2017): 71-87.
} 
confess I was a bit surprised that you're a theist now. Could you tell me more about it?"). Maybe Catherine has reasons that Miguel has not properly considered.

There is another reason why the conversion of a friend who was (at least previously) an epistemic peer is significant: we tend to attach more weight to the testimony of those who are close to us than to the testimony of strangers. Maybe this is because we can gauge the epistemic credentials of familiar individuals better. But familiarity alone does not explain the extra weight we accord to those near and dear to us. After all, if that were the case, we would put more stock in former friends or in frenemies, and this does not seem to be the case (indeed, we tend to be more cautious when it comes to both categories). Being friends engenders epistemic partiality. ${ }^{23}$ Already very young children show the tendency to value the testimony of people close to them more than the testimony of strangers. ${ }^{24}$ This heuristic makes sense in the context of epistemic vigilance: since we not only need to sort out accurate from inaccurate testifiers, but also those who are truthful from deceitful, it makes sense to trust people who are well disposed toward us. Thus people have a tendency to place selective trust in people they see as benevolent: people with whom we have a trusting relationship are less likely to deceive us. ${ }^{25}$

Trust in friends may also be valuable beyond purely epistemic reasons, just like self-trust is intrinsically valuable. ${ }^{26}$ Some feminist epistemologists have emphasized the value of certain kinds of partiality: intellectual theorizing should not be seen as purely dissociated from our emotional lives. ${ }^{27}$ For such reasons, Miguel should be more diligent in following up Catherine's reasons for converting. And perhaps likewise, Catherine should be diligent in following up with Miguel to explain her reasons for converting. I will now look at a case study of conversion that will illustrate why reasoned debate is the proper response to a friend's, and one's own, conversion.

\section{Rational argument and conversion}

The African theologian and church father Augustine of Hippo (354-430) converted from Manichaeism to Christianity. In both religious traditions, he was an apologist, a teacher, and an evangelist. The letter De Utilitate Credendi (The Usefulness of Belief ${ }^{28}$ is addressed to Honoratus, a student friend. Augustine converted his friend to Manichaeism with much difficulty, and in the letter set himself the unenviable task to try to convince his friend to convert to Christianity. But why should Honoratus, whom he previously persuaded of the merits of Manichaeism, now trust Augustine? As Asiedu

\footnotetext{
${ }^{23}$ Sarah Stroud, "Epistemic Partiality in Friendship," Ethics 116 (2001): 498-524.

24 Paul L. Harris and Kathleen Corriveau, "Young Children's Selective Trust in Informants," Philosophical Transactions of the Royal Society of London B 366 (2011): 1179-1187.

25 Dan Sperber, Fabrice Clément, Christophe Heintz, Olivier Mascaro, Hugo Mercier, Gloria Origgi, and Deirde Wilson, "Epistemic vigilance," Mind \& Language 25 (2010): 359-393.

${ }^{26}$ See, for a defense of the value of self-trust, Robert Pasnau, "Disagreement and the Value of Self-Trust," Philosophical Studies 172 (2015): 2315-2339.

27 Daniel Jayes O'Brien, "A Feminist Interpretation of Hume on Testimony," Hypatia 25 (2010): 632-652.

${ }^{28}$ Augustine, "The Usefulness of Belief (De Utilitate Credendi)," in Augustine: Earlier writings, ed. J.H.S. Burleigh (Philadelphia: Westminster Press, 391 [1953]), 284-323.
} 
writes,

For Augustine to achieve his purposes, Honoratus would have to be persuaded of Augustine's trustworthiness while discounting Augustine's much earlier evangelistic campaigns as a Manichee. Honoratus would also have to grant that Augustine himself had not been deceived a second time as he appears to have been misled the first time when he was persuaded by the Manichees. ${ }^{29}$

The letter is revealing in that Augustine does not point to his own conversion experience as a source of knowledge, as he does elsewhere (e.g., in his Confessions). ${ }^{30}$ Rather, the letter focuses on biblical hermeneutics (the discrepancies between the Old and New Testaments, which Manicheans often pointed out as reasons to reject Christianity) and on high-level epistemological principles such as trust and credibility. The letter focuses on the reasons Manicheans gave for rejecting Catholic doctrines, and argues that these reasons were mistaken. In this way, Augustine argues that Honoratus' (and his former self's) reasons for accepting the Manichaean doctrine were mistaken:

Well, they harangued at great length and with great vigour against the errors of simple people, which I have since learned is extremely easy for anyone to do who is moderately educated; and if they taught us any of their own doctrines we thought we must maintain it because nothing else occurred to us to set our minds at rest. ${ }^{31}$

The passage in viii, 20 recounts Augustine's own faith journey (what born-again Christians would call their "testimony"). He first reveals that he was already "in a state of serious doubt" about Manichaeism when he last parted from his friend, and that his doubt grew even more after he saw the underwhelming performance by the famous Manichean Faustus. "You remember, his coming to explain all our difficulties was held out to us as a gift from heaven. Well, I recognized that he was no better than the others of the sect, except for a certain eloquence he had." ${ }^{32}$ While Augustine does not use his own conversion as a source of evidence to Honoratus, he nevertheless presents it as a model that Honoratus can emulate. For example, he draws close parallels between his own former doubts (now happily resolved), and Honoratus' present doubts. This echoes the conciliationist position in the epistemology of disagreement, where the beliefs of others we respect as our peers provide significant evidence (in part because our peers may have reasons or arguments we may not have considered properly), and where these beliefs call for belief revision.

29 F.B.A. Asiedu, "The Limits of Augustine's Personal Authority: The Hermeneutics of Trust in De utilitate credendi," in Augustine and Liberal Education, ed. K. Paffenroth and K.L Hughes (Lanham: Rowman \& Littlefield, 2001), 124-145, 128.

${ }^{30}$ Augustine, Confessions (Vol 1) (translated by W. Watts) (Cambridge, MA: Harvard University Press, (4th century AD [2006]).

${ }^{31}$ The Usefulness of Belief, i, 2, 292.

${ }^{32}$ The Usefulness of Belief, viii, 20, 306. 
The letter (particularly sections vii-xi) develops an intricate philosophy of testimony, where Augustine asserts that all knowledge must begin in trust of those who have proper authority, rather than in reason. He gives the example of the trust we place in our parents:

... how will children serve their parents and love them with mutual dutifulness if they do not believe that they are their parents. That cannot be known by reason. Who the father is, is believed on the authority of the mother, and as to the mother, midwives, nurses, slaves have to be believed, for the mother can deceive, being herself deceived by having her son stolen and another put in his place. $^{33}$

To Augustine, the chief problem with Manicheans is that they do not recognize the importance of trust in testimony of those who have proper authority. Instead they hold up a mirage of how we should acquire beliefs: "they promise to give to those whom they attract a reason even for their most obscure doctrines." ${ }^{34}$ Thus, they are not being intellectually honest with their adherents and converts, because it is simply not possible to give reasons for obscure doctrines, without resorting to trust in authoritative testifiers. $^{35}$

In De Utilitate Credendi Augustine sees testimony merely as a basis of belief. In his Confessions (397-401) he also regards it as a basis for knowledge. ${ }^{36}$ Yet, in the former he clearly sees testimony as a precondition for knowledge, as many people would lack the relevant reasoning skills to work out religious truths for themselves. Augustine draws an illuminating parallel between friendship and trust in testimony. Against those who do not think that testimony can be a useful source of belief, Augustine argues, "I do not see how anyone who accepts that as true can ever have a friend. For if to believe anything is base, either it is base to believe a friend, or without such belief I cannot see how anyone can go on speaking about friendship. ${ }^{137}$ While it is not explicit, it is clear that Augustine here is appealing to his friend to read his arguments with more charity and patience than he would read the arguments from a Catholic writer he does not know, namely with the charity one owes a friend. The tone throughout the letter underlines this point, with Augustine frequently expressing understanding at what must be a surprise to his friend, for example, "You are amazed, I am sure. For I cannot pretend that I was not formerly of a very different opinion"; ${ }^{38}$ he frequently anticipates objections Honoratus might have, such as, "But you will probably ask to be given a plausible reason why, in being taught, you must begin with faith and not rather with

\footnotetext{
${ }^{33}$ The Usefulness of Belief, xii, 26, 313.

34 The Usefulness of Belief, ix, 21.

35 This holds also for those who study the sciences. At some point, one needs to trust those with authoritative knowledge, as it is impossible to experimentally verify everything for oneself.

${ }^{36}$ Peter King and Nathan Ballantyne, "Augustine on Testimony," Canadian Journal of Philosophy 39 (2008): 195-214.

${ }^{37}$ The Usefulness of Belief, x, 23, 309.

${ }^{38}$ The Usefulness of Belief, vi, 13, 301.
} 
reason." 39

Overall, De Utilitate Credendi shows a good model of peer disagreement in the face of conversion. Augustine's aims in the letter are modest. As he points out in his closing paragraphs, he does not refute the Manichean doctrines or defend Catholic ones. Rather, he aims to show that the arguments that Manicheans have offered against Catholic doctrines (namely, alleged discrepancies between the Old and $\mathrm{New}$ Testaments) are not as strong as he previously believed. He also argues that Manicheism does not live up to its own standards of belief based on reason, rather than testimony-a standard that Augustine also demonstrates to be unattainable. Along the way, Augustine can also demonstrate to himself (as he also did at length in his Confessions) that he is now in a better epistemic position than his pre-conversion self. Even though Augustine may not be justified in thinking he now holds the correct doctrines, his new beliefs are based on more sophisticated grounds, whereas his previous reasons for rejecting Catholic doctrines proved to be inadequate.

\section{Conclusion}

The case of religious conversion presents a series of difficulties for traditional accounts of epistemic peer disagreement, because conversion is a transformative experience: it is difficult to compare whether a convert is in a better epistemic position post-conversion. Conversion is rarely the outcome of a rational decision process, but the result of irrelevant causal factors such as the religious views of friends and personal tension. This was almost certainly the case for Augustine, as we can see in passages throughout De De Utilitate Credendi, for example, "When I departed from you across the sea I was already in a state of serious doubt; what was I to hold; what was I to give up? Indeed my hesitation grew greater day by day from the time that I heard the famous Faustus." 40 Most cases of conversion are not caused by forces that are more pernicious than the ones that gave rise to the original set of beliefs (e.g., beliefs of one's parents). Given that both self-trust and trust in friends is valuable (for epistemic and non-epistemic reasons), it does not seem wrong to accord prima facie weight to a friend's new set of beliefs, if one saw this friend as an epistemic peer prior to conversion. Rational argument and dialogue, as illustrated by Augustine, can play a crucial role in evaluating peer disagreement caused by conversion. It not only helps one's friends to critically evaluate their beliefs, but also allows the convert to critically reflect on her own.

\footnotetext{
${ }^{39}$ The Usefulness of Belief, ix, 22, 308.

${ }^{40}$ The Usefulness of Belief, viii, 20, 306.
} 